TOM X (2019)

\author{
Marcin Dyś \\ (Wydział Nauk Historycznych i Pedagogicznych, \\ Uniwersytet Wrocławski)
}

\title{
Przemiany narracji opisującej stosunki polsko- -rosyjskie w podręcznikach do nauczania historii w szkolnictwie ogólnokształcącym Polski Ludowej lat 1944-1989 (na przykładzie wybranych wydarzeń)
}

\section{Wstęp}

Historia jako przedmiot szkolny w czasach Polski Ludowej zajmowała ważne miejsce w siatce godzin przeznaczonych na edukację zarówno na szczeblu szkolnictwa podstawowego, jak i w procesie nauczania starszej młodzieży. Była przedmiotem istotnym dla władz, o czym może świadczyć fakt, że jednym z pierwszych programów nauczania po przejęciu władzy przez komunistów był właśnie program nauczania historii ${ }^{1}$, a uczeń w powojennej szkole już w drugim semestrze trzeciej klasy miał zetknąć się z tym przedmiotem. Wraz z kolejnymi dekadami malało jednak jej znaczenie - przynajmniej to wynikające z siatki godzin. Porównując początki Polski Ludowej z jej schyłkiem, można zauważyć, że liczba lekcji historii zmalała z $25^{2}$ do 17 w całym cyklu edukacyjnym ${ }^{3}$. Trudno jednak nie zgodzić się z opinią, że władze PRL przywiązywały do przedmiotu dużą wagę.

Historia w omawianym okresie stała się przedmiotem silnie zideologizowanym, mającym przedstawiać dzieje zgodnie z linią oficjalnej propagandy i komunistyczną wizją świata. Cytowany przez Krzysztofa Kosińskiego pracownik Wydziału

1 Ministerstwo Oświaty Rzeczypospolitej Polskiej. Zarządzenie Ministra Oświaty z dnia 24 marca 1945 r. o tymczasowym programie historii w szkołach średnich ogólnokształcących. Nr VI-2453/45. Dziennik Urzędowy Ministerstwa Oświaty, Warszawa, 1945, poz. 4, s. 10.

2 Dwie godziny historii w II semestrze klasy trzeciej szkoły podstawowej zostały policzone jako jedna godzina przez cały rok.

3 Szerzej: Marcin Dyś, „Siatka godzin nauczania historii w szkolnictwie ogólnokształcacym w Polsce w latach 1944-1989” w Edukacja 2010, red. Grażyna Pańko, Małgorzata Skotnicka, Barbara Techmańska (Opole-Wrocław-Lublin: Państwowy Instytut Naukowy, 2011), 170-176. 
Propagandy KC PPR w sierpniu 1945 r. mówił, że „dla treści ideowej szkoły najważ-

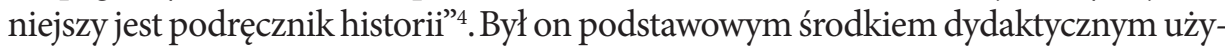
wanym przez nauczycieli i cieszącym się wśród szkolnej kadry dużą popularnością. W 1988 r., u schyłku PRL-u, prawie 70\% z nich deklarowało, że używa go na każdej lekcji, co było wynikiem zbliżonym do tego z poprzedniej dekady ${ }^{5}$. Nawet jeśli podręczniki nie odzwierciedlały do końca tego, co przekazywali nauczyciele, to można z całą pewnością stwierdzić, że treści podręcznika pokazują, czego od edukacji historycznej wymagały władze. Należy dodać, że podręczniki szkolne podlegały ścisłej ministerialnej kontroli, a sugestie dotyczące zawartości polskich książek władze dostawały nawet z ZSRR ${ }^{6}$. Treści, które można w nich znaleźć także były uzależnione od programów nauczania. Znaczenie podręcznika wzmagał dodatkowo fakt, że zazwyczaj była tylko jedna obowiązująca w danym czasie książka i służyła kilku rocznikom uczniów.

W swoim artykule starałem się udowodnić kilka tez - przede wszystkim, że narracja w podręcznikach, szczególnie w latach pięćdziesiątych, starała się spełniać kryteria stawiane przez oficjalną propagandę (np. forsowana jedność narodów słowiańskich czy traktowanie Niemiec jako głównego wroga) oraz, że często przedstawiała rosyjski, a nie polski punkt widzenia na daną sprawę. Ponadto chciałem ukazać występujący i odwołujący się do teorii walki klas marksizujący język oraz zmiany w narracji, które niewątpliwie zachodziły w omawianym okresie. Biorąc pod uwagę ograniczoną objętość artykułu wybrałem do tego celu dwa wydarzenia, które łączyły dzieje naszego wschodniego sąsiada z Rzeczpospolitą - mianowicie bitwę pod Grunwaldem oraz tzw. dymitriady, a więc początek wieku XVII. Swój wybór uzasadnię w rozdziałach im poświęconych.

$\mathrm{W}$ artykule dosyć często obszernie cytuję omawiane teksty, robię to jednak świadomie. Uważam bowiem, że warto pozwolić tym źródłom, by przemawiały same. Omówienia często gubią specyfikę zideologizowanej narracji, charakter języka, z którym musieli się mierzyć uczniowie i nauczyciele. Cytaty obrazują też, jak poszczególne wątki propagandowe się przenikają, dążąc do utworzenia w umysłach odbiorców spójnej całości.

Należy jeszcze w tym miejscu doprecyzować termin „Rosja” zawarty w tytule niniejszego artykułu, który jest swego rodzaju skrótem myślowym, słowem-kluczem na oznaczenie kolejnych tworów państwowych funkcjonujących bezpośrednio na wschód od ziem polskich.

4 Krzysztof Kosiński, O nową mentalność. Życie codziennie w szkołach 1945-1956 (Rzeszów: TRIO, 2002), 171.

5 Jerzy Maternicki, Czesław Majorek, Adam Suchoński, Dydaktyka historii (Warszawa: Wydawnictwo Naukowe PWN, 1993), 339-340; Mariola Hoszowska, Praktyka nauczania historii w Polsce 1944-1956 (Rzeszów: Wydawnictwo Uniwersytetu Rzeszowskiego, 2002), 179.

6 Szerzej: Zbigniew Osiński, Nauczanie historii w szkołach podstawowych $w$ Polsce $w$ latach 1944-1989 (Toruń, Dom Wydawniczy DUET, 2006), 211-212; Jerzy Brynkus, Komunistyczna ideologizacja a szkolna edukacja historyczna w Polsce (1944-1989) (Kraków: Antykwa, 2013), 451-452; Recenzja z Moskwy. O polskich podręcznikach historii (Warszawa: Głos, 1980). 


\section{Bitwa pod Grunwaldem ${ }^{7}$}

Bitwa pod Grunwaldem była w Polsce Ludowej kreowana na kluczowe wydarzenie w historii Polski. Wynikało to z kilku względów. Przede wszystkim pozwalało pokazać, że to Niemcy (a zatem w przeszłości także Krzyżacy) stanowili główne zagrożenie dla suwerenności Polski i zawsze byli gotowi podstępnie napaść na nasz kraj. Ponadto na polach Grunwaldu walczyli oprócz Polaków także Czesi i Rusini, a więc bitwa dawała doskonałą możliwość podkreślania przyjaźni międzysłowiańskiej i braterstwa broni w momentach istotnych dla dalszych losów naszej ojczyzny. W późniejszych dekadach Polski Ludowej komuniści zaczęli odwoływać się także do dawniejszej tradycji obchodów zwycięstwa pod Grunwaldem, sięgającej co najmniej roku 1910, gdy uroczystości w Krakowie stały się okazją do spotkania międzyzaborowego, a także z przedstawicielami polskiej emigracji z różnych krajów, i służyły umacnianiu tożsamości narodowej i podsycaniu dążeń niepodległościowych Polaków.

Jeszcze przed formalnym stworzeniem komunistycznego państwa, w ZSRR, utworzono polskie siły zbrojne pod dowództwem generała Berlinga - symboliczna jest tutaj data złożenia przysięgi przez żołnierzy I Dywizji - 15 lipca 1943 r. Później obywatele Polski Ludowej mogli zetknąć się z Orderem Krzyża Grunwaldu, plakatem „Grunwald 1410 - Berlin 1945”, filmem Aleksandra Forda Krzyżacy, wizerunkiem dwóch mieczy na banknocie pięćdziesięciozłotowym czy nad wyraz hucznymi obchodami rocznic starcia. Ciągłość niemieckiego zagrożenia odzwierciedlał znany plakat propagandowy ukazujący kanclerza Adenauera w płaszczu z czarnym krzyżem.

W podręcznikach szkolnych bitwa pod Grunwaldem również zajmowała ważne miejsce, była opisywana dość szczegółowo i barwnie. Wyraźnie chodziło nie tylko o przedstawienie faktów, lecz również o oddziaływanie na emocje i pamięć młodych odbiorców. Warto prześledzić, jak zmieniało się jej przedstawianie w kolejnych dekadach PRL.

W końcu lat czterdziestych i w latach pięćdziesiątych koncentrowano się na ukazaniu jedności państw słowiańskich, zwracając szczególną uwagę na udział i rolę wojsk ruskich w bitwie.

W podręcznikach wydanych tuż po wojnie (tj. w 1946 r.) Rusini w ogóle nie występowali w opisie walk. Szybko ten propagandowy błąd został jednak naprawiony i od $1947 \mathrm{r}$. nie można było znaleźć książki bez wzmianki dotyczącej udziału, odwagi wojsk smoleńskich i ich decydującego wpływu na przebieg działań zbrojnych. Żeby to zauważyć, warto porównać dwa wydania książek Jana Dąbrowskiego: „Dopiero w czerwcu 1410 r. wojska polskie i litewskie [tu i w dalszej części wyróżnienia oraz komentarze - M.D.] połączywszy się na Mazowszu ruszyły stamtąd

Warto zaznaczyć, że temat ukazywania bitwy grunwaldzkiej w podręcznikach szkolnych był juz poruszany - np. Agnieszka Chłosta-Sikorska, „Bitwa pod Grunwaldem w polskich podręcznikach do historii", Res Gestae 11 (2015): 147-169. 
wprost na Malbork, stolicę Zakonu. [...] Wobec marszu Polaków na Malbork wielki mistrz przeprowadził pośpiesznie główne siły krzyżackie na prawy brzeg Wisły i 15 lipca 1410 r. w pobliżu wsi Grunwald i Tannenberg zastąpił drogę wojskom polskim i litewskim zmierzającym na północ [...]. Wojska polskie i litewskie przewyższały Krzyżaków nieco liczbą, ale Krzyżacy mieli za to przewagę ciężkiej jazdy rycerskiej, dobrze uzbrojonej. [...] Na początku bitwy zmusił też atak krzyżacki do odwrotu Litwinów zostających pod wodzą Witolda; cały ciężar walki spadł na mocno uszykowane wojska polskie, które wytrzymawszy napór Krzyżaków poczęły spychać ich ku wsi Grunwaldowi”". W 1947 uczniowie zapoznawali się już z następującą relacją: „Armia królewska występująca przeciw Krzyżakom złożona z Polaków, Litwinów i Rusinów wspomaganych przez zaciągi śląskie i czeskie przewyższała nieco liczbą Krzyżaków, mających za to przewagę ciężkiej, dobrze uzbrojonej jazdy rycerskiej. Przez pewien czas toczone ciężkie zapasy nie przynosiły rozstrzygnięcia, a wówczas Krzyżacy uderzyli znaczną częścią swego ciężkiego rycerstwa na prawe skrzydło wojsk królewskich, na którym walczyły lżej od Krzyżaków uzbrojone wojska litewsko-ruskie"9.

W podręcznikach podkreślano jedność państw słowiańskich wobec zagrożenia, a także współpracę pomiędzy klasami chłopów i rycerzy: „W wyznaczonym czasie ze wszystkich stron Polski ściągali rycerze prowadząc z sobą zbrojne oddziały. Szli na tę wielką wojnę także i chłopi, zwłaszcza ci z pogranicza, którzy najwięcej ucierpieli od Krzyżaków. Z ziem litewskich i ruskich należących wówczas do Litwy, a nawet z Czech ciągnęli również wojownicy”" „Wzięły w niej [bitwie] udział obok wojsk polskich i litewskich, pułki ruskie i oddziały czeskie husyckie. [...] Sprzymierzone wojska słowiańskie i litewskie pod dowództwem Jagiełly i Witolda ruszyły na Malborg, stolicę Zakonu"11. Nawet tytuły rozdziałów podkreślały jedność i współpracę Polaków i Rusinów: „[...] Rozgromienie Zakonu Krzyżackiego wspólnymi siłami - Polski, Litwy i Rusi”12. Było to zatem starcie świata słowiańskiego i germańskiego.

W świecie słowiańskim szczególnie dużo uwagi poświęcano męstwu kilku pułków smoleńskich, bez których wygrana pod Grunwaldem byłaby (wobec złamania sił litewskich, a nawet polskich) niemalże niemożliwa. Przodowali w pisaniu w taki sposób pisarze radzieccy, których książki były tłumaczone na język polski, ale także polscy autorzy nie unikali tego typu sugestii. W wydanym w 1947 r. podręczniku dla szkoły podstawowej możemy przeczytać:

8 Jan Dąbrowski, Historia średniowieczna i nowożytna (Kraków: Wydawnictwo Księgarni S. Kamińskiego, 1946), 115-116.

9 Jan Dąbrowski, Historia średniowieczna i nowożytna (Kraków: Wydawnictwo Księgarni S. Kamińskiego, 1947), 106.

10 Anna Klubówna, Jadwiga Stępieniowa, W naszej ojczyźnie (Warszawa: PZWS, 1957), 38-39.

11 Żanna Kormanowa, red., Historia Polski (Warszawa: PZWS, 1951), 42-43; podobnie Mateusz Siuchiński, red. Historia dla klasy VI (Warszawa: PZWS, 1953), 69-70.

12 Stanisław Arnold, red., Historia Polski do 1795 roku (Warszawa: PZWS, 1956), 102. 
„Wyróżniły się natomiast i okryły sławą trzy ruskie pułki smoleńskie, którymi dowodził jeden $z$ braci Jagiełły. Twardo stały przy swych znakach; w jednym pułku wyginęli wszyscy żołnierze, dwa pozostałe biły się do końca i złączyły się później z polskimi chorągwiami”'13. Podręcznik Evgenija Kosminskiego stwierdzał: „Bitwę rozpoczęła jazda litewska atakując lewe skrzydło wojsk niemieckich. Niemcy w przeciwnatarciu złamali Litwinów i rzucili się za nimi zagrażając flankom i tyłom wojsk sprzymierzonych. Zachwiali się i Polacy; spadł na ziemię sztandar królewski. Krytyczne położenie uratowały dzielne pułki smoleńskie, które mężnie utrzymywały się w centrum walki mimo olbrzymich strat, zadawanych im przez Niemców. Męstwo ich umożliwiło Polakom przejście do przeciwuderzenia, które zakończyło się rozgromieniem wojsk zakonnych"14. Również w później wydanych książkach z lat pięćdziesiątych opis walki był bardzo dynamiczny i uwzględniał wojska ze wschodu: „Pierwsze ruszyły do walki chorągwie litewsko-ruskie. Krzyżacy skierowali na nie główne uderzenie. Chorągwie litewsko-ruskie, lekko uzbrojone, nie mogły wstrzymać nacisku przeważających sił ciężkozbrojnych szyków krzyżackich i zaczęly się cofać opuszczając pole walki. Tylko trzy chorągwie smoleńskie nie ustąpiły z pola i przyjęły na siebie cały ciężar ataku krzyżackiego. Miało to duże znaczenie, gdyż w ten sposób osłoniły one skrzydło polskie [...]”"15; „Szczególnym męstwem odznaczały się oddziały ruskie z okolic Smoleńska, które mimo olbrzymich strat w ludziach nie cofnęły się z pola walki"16. Także w plastycznych opowiadaniach dla szkoły podstawowej z końca dekady czytamy: „Skórami okryci Litwini nie mogli wytrzymać natarcia Krzyżaków osłoniętych żelaznymi zbrojami. Toteż część z nich zaczęła się cofać i uciekać w popłochu. Na próżno dzielny książę Witold nawoływał ich i próbował zatrzymać. Tylko ruscy rycerze ze Smoleńska wytrwali na stanowisku walcząc mężnie. Większa część tych rycerzy poległa, a reszta złączyła się z walczącym rycerstwem polskim, które szybko przygotowało się do odparcia nowego ataku"17. Litwini przedstawiani byli więc jako lud prymitywne uzbrojony (noszą skóry), niekarny. Natomiast pułki smoleńskie to rycerze (a więc pewnie w zbrojach), gotowi do największych ofiar, którzy po odegraniu swojej samodzielnej roli łączą się z Polakami - jest więc przykład polsko-ruskiego braterstwa broni. Podobne wnioski można wysnuć, czytając także starsze podręczniki, w których tworzeniu brała udział Władysława Hoszowska: „Ale oto, gdy Polacy zawzięcie mocują się z rycerstwem krzyżackim, Litwini nie mogą wytrzymać naporu żelaznych hufców i rzucają się do ucieczki. Rycerstwo polskie

13 Wanda Moszczeńska, Hanna Mrozowska, Podręcznik historii. Część 1 (Warszawa: PZWS, 1947), 78.

${ }_{14}$ Evgenij Kosminski, Historia wieków średnich (Warszawa: Nasza Księgarnia, 1950), 168.

15 Arnold, Historia Polski do 1795 roku, 110.

16 Siuchniński, Historia dla klasy VI, 70.

17 Władysława Hoszowska, Opowiadania z dziejów Polski. Część 1 (do roku 1505) (Warszawa: PZWS, 1958), 127. 
przy pomocy oddziałów ruskich - pułków smoleńskich - musiało samotnie dotrzymywać placu prawie całej nawale krzyżackiej"18.

Lata sześćdziesiąte to okres nakładania się podręczników z lat pięćdziesiątych (np. obowiązywały jeszcze takie książki jak: A. Klubówna, J. Stępieniowa, W naszej ojczyźnie ${ }^{19}$; red. S. Arnold, Historia Polski do 1795 roku²) z gamą zupełnie nowych, opracowanych dla szkoły ośmioletniej i obowiązujących przez całą kolejną dekadę, a nawet początek lat siedemdziesiątych ${ }^{21}$. Zasadniczo nie widać zdecydowanych różnic w opisie bitwy, akcentowane są dokładnie te same elementy. Warto jednak zwrócić uwagę, że zwycięstwo nie zależało już tylko od męstwa Rusinów, a wspomniany wcześniej sztandar został podniesiony przez polskich rycerzy (a nie, jak mógłby sugerować opis z lat pięćdziesiątych, przez pułki smoleńskie). Niemniej jednak nadal podkreślano waleczność oddziałów ze wschodu. Stanisław Szostakowski opisywał całość bitwy w sposób bardzo plastyczny: „Wśród wojsk litewskich znajdowały się oddziały ruskie i pewna liczba Tatarów. Przybyły także trzy zaciężne pułki czeskie. [...] Bitwa trwała już prawie godzinę, lecz żadna ze stron nie uzyskała przewagi. Krzyżacy postanowili wtedy główny atak skierować na Litwinów. Byli oni gorzej uzbrojeni niż wojsko polskie. Wielu z nich zamiast zbroi miało tylko skórzane kaftany. Nie wytrzymawszy uderzenia krzyżackiego, część Litwinów rzuciła się do ucieczki. Pozostały na placu boju jedynie trzy oddziały ruskie. Otoczone przez wroga parły ku Polakom. Jeden z oddziałów został w całości wycięty, lecz dwa pozostałe przedarły się do wojsk polskich. Walcząc dzielnie dotrzymały one pola Krzyżakom. W czasie najbardziej zaciętej walki, kiedy zwycięstwo przechylało się na jedną, to na drugą stronę, upadła na ziemię najważniejsza chorągiew polska ze znakiem Orła Białego. Z tysięcy krzyżackich ust podniósł się okrzyk tryumfu. Lecz radość wrogów była przedwczesna. Co dzielniejsi rycerze polscy natychmiast chorągiew podnieśli i z jeszcze większą zaciętością rzucili się do walki”22.

W latach siedemdziesiątych opis bitwy zaczyna się dość diametralnie zmieniać. Wprawdzie nadal wspomina się o udziale innych wojsk niż polskie (odziały litewskie, ruskie czy tatarskie), jednak ich rola znacznie maleje - uciekają z pola bitwy lub zostają po prostu rozbite. W opisie walki nie ma już wielu wzmianek o bohaterstwie Rusinów. Uczeń szkoły podstawowej w zasadzie dowiadywał się tylko, że wzięli udział w bitwie: „Pod rozkazami Władysława Jagiełły znalazło się rycerstwo i oddziały chłopskie znad Wisły i Warty, lekka i zwinna

18 Władysława Hoszowska, Tomasz Szczechura, Weronika Tropaczyńska-Ogarkowa, Było to dawno - opowiadania z dziejów ojczystych dla IV klasy szkoły podstawowej (Warszawa: PZWS, 1948), 75.

19 Do roku szkolnego 1962/1963.

20 W roku szkolnym 1961/1962 do roku szkolnego 1967/1968 z kosmetycznymi zmianami niewpływającymi na obraz bitwy pod Grunwaldem.

${ }_{21}$ Np. Stanisław Szostakowski, Historia dla klasy VI obowiązywał od roku szkolnego 1962/1963 do roku 1974/1975.

22 Stanisław Szostakowski, Historia dla klasy VI (Warszawa: PZWS, 1972), 7-10. 
jazda litewska, bitne pułki ruskie oraz podlegli Witoldowi Tatarzy. Krzyżaków wspierali "goście« z Europy Zachodniej. [...] Rozgorzała zacięta walka, szala zwycięstwa przechylała się to na jedną, to na drugą stronę. W pewnym momencie zwinne chorągwie litewskie zaczęły uciekać, część sił krzyżackich ruszyła za nimi. Tymczasem Litwini powrócili na pole walki. Po południu mistrz rzucił do walki swe przyboczne chorągwie, jednakże nic już nie zdołało zapewnić mu zwycięstwa. Zginął on sam, wielu rycerzy i niemal cała starszyzna zakonna. Przed zachodem słońca zapanował spokój. Główny ciężar walki spoczywał na ciężkozbrojnym rycerstwie, ale swoje zadanie spełniła również lekka jazda, łucznicy litewscy i polska piechota chłopska [a o pułkach smoleńskich mowy nie ma]. Wielu Krzyżaków oraz ich "gości« dostało się niewoli" ${ }^{23}$. W podręczniku dla liceum były już tylko oddziały „litewsko-ruskie”: „Natomiast Jagiełło ściągnął rycerzy polskich, pozostających dotąd w służbie obcych monarchów, i uzyskał pomoc ochotników ze Śląska i z Czech oraz posiłki lennej Mołdawii. W litewsko-ruskich wojskach Witolda znalazł się także oddział tatarski. [...] Bitwę rozpoczęło na skrzydle północnym natarcie lekkich oddziałów litewsko-ruskich, które wprowadziły pewne zamieszanie w szyki nieprzyjacielskie, ale następnie poniosły klęskę w starciu z ciężką jazdą krzyżacką i zostały rozproszone. Natomiast na skrzydle południowym Krzyżacy nie zdołali przełamać oporu Polaków, choć wielki mistrz rzucił tu ostatnie swoje odwody. W fazie bitwy wojska polsko-litewskie otoczyły z obu stron przeciwnika i niemal doszczętnie zniszczyły jego siły. Pole zasiały trupy wyborowego rycerstwa krzyżackiego, poległ również sam wielki mistrz"24.

Lata osiemdziesiąte to także w szkole podstawowej kolejny etap degradacji roli oddziałów ruskich w bitwie. Podręcznik do klasy IV szkoły podstawowej w ogóle nie wspomina o udziale wojsk innych niż polskie i litewskie, co może wynikać także ze skrócenia opisu samej bitwy: „To rycerze w białych płaszczach uciekali przed zwycięskimi Polakami i Litwinami” 25 ; „Doszło do wielkiej bitwy pod Grunwaldem, w której zwyciężyły wojska polsko-litewskie"26. Obraz przedstawiany starszym uczniom był nieco bardziej zbliżony do tego z poprzedniej dekady, a więc ograniczono się do wzmiankowania obecności oddziałów ruskich: „Pod jego [Jagiełły] rozkazami znalazło się polskie rycerstwo, lekka jazda litewska, pułki ruskie, a nadto podlegli Witoldowi Tatarzy oraz grupa ochotników czeskich. [...] Kiedy rozgorzała zacięta walka, szala zwycięstwa przechylała się to na jedną to na drugą stronę. W pewnym momencie Litwini rzucili się do ucieczki, ale wkrótce, ku zaskoczeniu wroga, wrócili na pole walki. Po południu mistrz rzucił do boju rezerwy, to jest

23 Marceli Kosman, Historia dla klasy VI (Warszawa: WSiP, 1975), 8-10.

${ }^{24}$ Jerzy Dowiat, Historia dla klasy I liceum ogólnokształcącego (Warszawa: WSiP, 1980), 454-457. Podręcznik obowiązywał w latach 1967-1988.

${ }_{25}$ Jerzy Centkowski, Andrzej Syta, Z naszych dziejów (Warszawa: WSiP, 1981), 34.

26 Centkowski, Syta, $Z$ naszych dziejów, 36. 
przyboczne swoje chorągwie. Nie na wiele się to zdało, zginął sam, wielu rycerzy i niemal cała starszyzna zakonna" 27 .

Opis bitwy niewątpliwie był najbardziej ideologicznie i propagandowo nacechowany w podręcznikach $\mathrm{z}$ lat pięćdziesiątych, których autorzy nie wyobrażali sobie wygranej pod Grunwaldem bez sojuszniczej pomocy pułków ruskich. Widać też w narracji elementy marksistowskiej teorii klasowej. Silnie akcentowano także braterstwo broni i jedność narodów słowiańskich. Stopniowo jednak obraz ten ewoluuje, oddziaływanie propagandowe słabnie, a w latach osiemdziesiątych rola Rusinów została prawie całkowicie zmarginalizowana.

\section{Rosja w początkach XVII w. - dymitriady}

Do omówienia wybrałem wydarzenia z początku wieku XVII, ponieważ ich prezentacja niewątpliwie stanowiła wyzwanie dla autorów podręczników do polskich szkół. Dwie polskie interwencje, $w$ tym jedna prowadzona zupełnie oficjalnie, wyniesienie na tron uzurpatorów popierających polską politykę, bunty ludowe, bolesne dla Rosjan zwycięstwo hetmana Żółkiewskiego pod Kłuszynem czy zaoferowanie tronu Władysławowi IV Wazie i odrzucenie tej propozycji przez Zygmunta III Wazę wyglądały zupełnie inaczej z perspektywy rosyjskiej niż polskiej.

Jako podstawę polskiej interwencji w Moskwie autorzy podręczników przez cały omawiany okres podawali trudności wewnętrzne wschodniego sąsiada, które Rzeczpospolita mogła wyzyskać dla zdobycia nowych ziem. Szczególne miejsce zajmowały tu traktowane $\mathrm{z}$ dużą sympatią powstania chłopskie ${ }^{28}$ oraz kryzys dynastyczny: „Na początku XVII wieku państwo moskiewskie przeżywało okres [...] walk domowych. Ucisk wieśniaków był coraz większy. Wskutek nieurodzaju zapanował straszny głód. W wioskach i miastach wybuchały rozruchy. Jednocześnie po śmierci małoletniego następcy tronu, carewicza Dymitra, wygasła rodzina carów. Wśród bojarów zaczęły się spory o carską koronę" 29 . W podobnym tonie wypowiadał się podręcznik Władysława Chłapowskiego i inne $e^{30} z$ kolejnych dekad: „Lata głodu wzmogły nędzę i nienawiść mas ludowych do cara, wzrastał opór chłopów, mnożyły się bunty. Opozycja bojarska czekała na sprzyjający moment, by obalić Borysa Godunowa i objąć władzę w państwie" ${ }^{31}$. Stosunkowo najbardziej

27 Marceli Kosman, Historia. Wielkość i upadek Rzeczpospolitej szlacheckiej. Podręcznik dla klasy VI szkoły podstawowej (Warszawa: WSiP, 1984), 22-24.

28 Np. Wanda Moszczeńska, Hanna Mrozowska, Podręcznik historii część 1 (Wrocław: PZWS, 1948), 171-172.

29 Kormanowa, Historia Polski, 83.

30 Poza cytowanymi np. także: Kosman, Historia, 79 czy Józef Gierowski, Józef Leszczyński, Historia dla klasy II liceum ogólnokształcącego (Warszawa: WSiP, 1980), 215.

${ }_{31}$ Władysław Chłapowski, Historia średniowieczna (Warszawa: PZWS, 1958), 342. Podobnie Władysława Hoszowska, Opowiadania z dziejów Polski. Część druga (1505-1648) (Warszawa: PZWS, 
lakoniczna była książka Szostakowskiego z lat siedemdziesiątych: „W początkach XVI wieku panował w Rosji zamęt i nieporządek"'32.

Nie ulega wątpliwości, że według autorów podręczników interwencja w Rosji miała przysłużyć się nie ogółowi polskiego społeczeństwa, ale głównie magnaterii, która liczyła na rozwój swoich latyfundiów. Stąd też magnaci ochoczo wspierali zabiegi obu Samozwańców. Grupa ta, określana także mianem „panów”, szczególnie często pojawiała się w narracji. Na początku lat pięćdziesiątych pisano o niej z wyraźną niechęcią i łączono z jezuitami (co zwykle służyło potęgowaniu ocen negatywnych): „Chciwie spoglądali magnaci polscy na olbrzymie przestrzenie [to $\mathrm{z}$ kolei określenie buduje przekonanie o potędze Moskwy] państwa moskiewskiego. Zaborcze plany magnatów polskich znajdowały poparcie jezuitów, którzy chcieli również pozyskać te ziemie dla swoich wpływów"33. W podręczniku pod redakcją Stanisława Arnolda mogliśmy przeczytać: „Próby podboju Rosji zakończone niepowodzeniem za Batorego zostały znowu podjęte przez polskich magnatów na początku XVII w. [podkreślana jest więc ciągłość zaborczych dążeń polskich ${ }^{34}$. [...] Wybuchały powstania chłopów. [...] Tę sytuację starali się wykorzystać panowie polscy przez wmieszanie się w wewnętrzne sprawy Rosji. [...] Wszyscy zdawali sobie sprawę, że Dymitr to samozwaniec, niemniej dla poparcia pretensji rzekomego Dymitra do tronu rosyjskiego magnaci zorganizowali zbrojną wyprawę. W zamian za uzyskanie tronu rosyjskiego Dymitr miał hojnie zapłacić. Panowie polscy mieli uzyskać liczne nadania ziem rosyjskich"35. W kolejnych dekadach opis ten nieco się skraca, ale nie zmienia się w sposób diametralny, autorzy piszą bardzo podobnie ${ }^{36}$ - „Magnaci polscy, popierający Samozwańca, liczyli na zdobycie ziem rosyjskich, uzyskanie tam wpływów i korzyści” ${ }^{37}$; „[...] niektórzy magnaci polscy wysunęli na tron rosyjski awanturnika nieznanego pochodzenia, który podawał się za Dymitra, syna Iwana IV. W ten sposób magnaci polscy chcieli zdobyć wpływy w Rosji” 38 .

Interpretacja samej interwencji nie była tak niezmienna. Wprawdzie przez cały omawiany okres na tron carski wydźwignęli Samozwańców polscy magnaci wspierani mniej lub bardziej oficjalnie przez Zygmunta III Wazę, jednak w latach pięćdziesiątych znacznie ułatwiła im to zdrada bojarów. Mieliśmy zatem do czynienia $\mathrm{z}$ wyraźną dominacją klasowej interpretacji dziejów: „W porozumieniu z częścią bojarów magnaci polscy osadzili Dymitra Samozwańca na tronie carskim. [...]

1960), choć ona bojarów przede wszystkim oskarża o gnębienie chłopów, którzy z tego powodu przyłączyli się do dymitriad, licząc na poprawę swego losu.

${ }_{32}$ Szostakowski, Historia dla klasy VI, 98.

33 Siuchniński, Historia dla klasy VI, 149.

34 Podobnie Siuchniński, Historia dla klasy VI, 149.

35 Arnold, Historia Polski do 1795 roku, 224.

36 Poza cytowanymi np. także Kosman, Historia, 79 czy Gierowski, Leszczyński, Historia dla klasy II liceum ogólnokształcącego, 215.

37 Chłapowski, Historia średniowieczna, 343.

38 Szostakowski, Historia dla klasy VI, 98. 
Liczył [Żółkiewski], że część bojarów poprze zabór polski ze strachu przed powstaniem ludu. Istotnie pod murami Moskwy stanął z częścią bojarów układ, że królewicz Polski Władysław, dopuściwszy do współrządów bojarów, zostanie carem moskiewskim"39. Jeszcze dalej posunął się Kosminski, który zarzucił zdradę całej warstwie bojarów: „Rząd polski przeszedł teraz od poprzedniej taktyki dywersyjnej do otwartej interwencji. Król Zygmunt III otoczył Smoleńsk. Wówczas Szujskiego zrzucono z tronu, a bojarowie, którzy ujęli teraz w swe ręce ster rządów, otworzyli Polakom bramy Kremla" ${ }^{30}$. Autorzy z czasów stalinowskich ani razu nie wspominają o wielkim polskim zwycięstwie hetmana Żółkiewskiego pod Kłuszynem, które umożliwiło atak na stolicę Rosji, i - jak widać na podanych przykładach - zrzucają odpowiedzialność na bojarów. Znaczenie bitwy dostrzega np. podręcznik pod redakcją Stanisława Arnolda, ale i on nie pozostawia złudzeń, kogo należy winić za oddanie Moskwy Polakom, a starcie przedstawił jako potyczki dwóch prywatnych armii: „Pod Kłuszynem wojska polskie pod wodzą hetmana Żółkiewskiego rozgromiły armię Szujskiego. Zwycięstwo pod Kłuszynem otworzyło wojskom polskim pod wodzą hetmana Żółkiewskiego drogę do Moskwy [...]. W obawie przed wybuchem w Moskwie powstania ludowego, a także przed opanowaniem miasta przez Samozwańca, [...] bojarzy obalili cara Szujskiego, weszli w porozumienie $\mathrm{z}$ hetmanem Żółkiewskim i wpuścili do stolicy wojska polskie. Porozumienie zawarto na następujących warunkach: carem miał zostać królewicz Władysław [...]. Miał on przyjąć prawosławie i sprawować rządy wraz z bojarami” ${ }^{41}$.

Podręcznik Chłapowskiego, który obowiązywał od końca lat pięćdziesiątych po koniec kolejnej dekady, także dostrzegł zarówno znaczenie starcia pod Kłuszynem, jak i postawę bojarów mającą zapewnić im utrzymanie części władzy: „Po klęsce pod Kłuszynem (1610) bojarowie usunęli z tronu Szujskiego i ofiarowali koronę carską królewiczowi polskiemu Władysławowi. Moskwę obsadziła załoga polska"ł2.

Podręczniki z lat siedemdziesiątych i osiemdziesiątych mówiły po prostu o zdobyciu Moskwy przez Polaków lub bardziej bezosobowo o dotarciu wojsk pod Moskwę, „która otworzyła przed nim [Żółkiewskim] bramy”", a rosyjscy bojarzy już nie „układają się”, czy „wchodzą w porozumienie” z Żółkiewskim, lecz po prostu zgadzają się na postawione warunki: „Wojska polskie pod dowództwem hetmana Stanisława Żółkiewskiego odniosły zwycięstwo pod Kłuszynem (1610). Wówczas część bojarów rosyjskich zgodziła się powołać na tron syna Zygmunta III, Władysława. Hetman Żółkiewski wkroczył ze swoimi wojskami do Moskwy"44. W niektórych opracowaniach, począwszy od lat siedemdziesiątych, nie pojawiają się bojarzy, lecz mowa po prostu o Rosjanach: „Zwycięski wódz wjechał triumfalnie

39 Kormanowa, Historia Polski, 84-85.

40 Evgenij Kosminski, Historia wieków średnich (Warszawa: Nasza Księgarnia, 1953), 266.

41 Arnold, Historia Polski do 1795 roku, 226.

42 Chłapowski, Historia średniowieczna, 344.

43 Gierowski, Leszczyński, Historia dla klasy II liceum ogólnokształcącego, 216.

44 Szostakowski, Historia dla klasy VI, 98. 
na Kreml. Rosjanie zgodzili się ogłosić carem królewicza Władysława, pod warunkiem, że przyjmie prawosławie"45.

Pod koniec lat czterdziestych i w latach pięćdziesiątych zdecydowanie dominuje obraz interwencji niesprawiedliwej, zaborczej - expressis verbis tak właśnie ocenianej. W tym tonie utrzymany jest podręcznik pod redakcją Kormanowej: „W wyprawach tych polscy magnaci sięgali po cudze ziemie. Poparł ich w tym król Zygmunt III. Chciał podbić Moskwę. Ale naród rosyjski obronił swoją samodzielność zachowując głęboki żal do najeźdźców. Była to więc ze strony magnatów i ze strony szlacheckiej Rzeczypospolitej wojna niesprawiedliwa" ${ }^{\text {"46 }}$. W najlepszym przypadku była to wyprawa „awanturnicza”, „nieszczęśliwa”, podczas której zdecydowanie niepotrzebnie przelewano krew: „I w otoczeniu królewskim, w sejmie i w senacie odzywały się głosy (jak głos hetmana Żółkiewskiego) ostrzegające przed wyprawą, wskazujące na jej awanturniczość. Nie znalazły one jednak posłuchu”" rozpoczęła wojnę z Moskwą" ${ }^{8}$; „Przez długie lata toczyły się zacięte walki, a wiele krwi z obydwóch stron zostało niepotrzebnie przelanej" ${ }^{49}$. W kolejnych dekadach nie odnajdziemy już w podręcznikach tak pejoratywnych określeń, unikają one oceniania interwencji w jakikolwiek sposób. Jedynym wyjątkiem może być podręcznik Stanisława

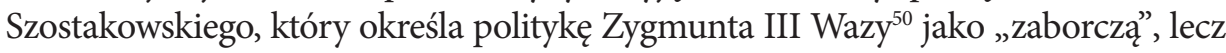
przymiotnik ten pada bardziej w kontekście przekazania mu carskiej korony i narzucenia katolicyzmu, a nie podbojów: „Do wyboru Władysława jednak nie doszło, ponieważ przeciwstawił się temu Zygmunt III. Chciał on sam zostać carem, połączyć Rosję z Rzeczpospolitą i narzucić jej katolicyzm. [...] Dążenie Zygmunta III do narzucenia Rosji katolicyzmu i jego zaborcza polityka wywołały oburzenie Rosjan"51.

Należy też zwrócić uwagę na to, że interwencja w Rosji przez cały omawiany okres była pokazywana jako przedsięwzięcie wąskiej grupy ludzi, odizolowanych od ogółu społeczeństwa Rzeczypospolitej. Nie była to polityka państwa czy interes narodu, raczej prywatne działania króla, części magnaterii i ich sił zbrojnych ${ }^{52}$. W czasach stalinowskich dodatkowo stwierdzano: „Ceną zapłaconą przez Pol-

45 Kosman, Historia dla klasy VI, 93; Kosman, Historia, 79.

46 Kormanowa, Historia Polski, 85.

47 Arnold, Historia Polski do 1795 roku, 226.

48 Moszczeńska, Mrozowska, Podręcznik historii. Część 1, 153.

49 Stanisław Zajączkowski, red., Podręcznik historii dla klasy VII szkoły podstawowej (Warszawa: PZWS, 1947), 276.

50 Król był bardzo krytycznie oceniany przez podręczniki z czasów PRL, głównie ze względu na swoje przywiązanie do katolicyzmu - zob. Joanna Wojdon, Propaganda polityczna w podręcznikach dla szkół podstawowych Polski Ludowej (1944-1989) (Toruń: Wydawnictwo Adam Marszałek, 2001), 227-228.

${ }^{51}$ Szostakowski, Historia dla klasy VI, 98. Motyw religijny podkreśla też Władysława Hoszowska, Opowiadania z dziejów Polski. Część druga (1505-1648) (Warszawa: PZWS, 1960), 98-99.

${ }_{52}$ Np. Hoszowska, Opowiadania z dziejów Polski. Część druga (1505-1648), 99: „Wojny Polski z Rosją osłabiły oba państwa, a korzyść przyniosły tylko magnatom, którzy rozszerzyli swe posiadłości na ziemiach ruskich". 
skę za możność prowadzenia wojny na wschodzie było zaprzepaszczenie sprawy pruskiej" ${ }^{33}$. Rzucała się także cieniem na wzajemnych stosunkach między narodami: „Ta lekkomyślna wyprawa polskich panów na Moskwę pozostawiła jednak doniosłe skutki. Lud moskiewski zapamiętał na długo ten najazd na jego ziemię w ciężkiej chwili głodu i zamętu"s4.

Przez cały omawiany okres nie ulegało wątpliwości, że ostatecznie Polaków z Moskwy wypędzono pod przywództwem drobnej szlachty siłami całego narodu rosyjskiego, który zbuntował się przeciw najeźdźcom ${ }^{55}$, a zasadnicze zasługi w zwycięstwie położyły warstwy niższe: mieszczanie i chłopi. „W Moskwie wybuchło powstanie ludowe. Na czele powstańców stanęli mieszczanin Minin i książę Pożarski. Mieszkańców Moskwy poparli chłopi" ${ }^{\text {"56 }}$. Charakterystyczne jest to, że niekorzystne dla Rosji wydarzenia były najczęściej dziełem bojarów lub cara, a sukcesy przypisywano nieuprzywilejowanym klasom społecznym. Mowa była też o ogólnonarodowym powstaniu i oburzeniu ogółu społeczeństwa ${ }^{57}$. Głównymi postaciami, które pojawiały się w podręcznikach z czasów stalinowskich przy okazji usuwania wojsk polskich z Moskwy byli mieszczanin Kuźma Minin oraz kniaź Dymitr Pożarski. Warto również odnotować pojawiającą się w książce radzieckiej międzynarodową antypolską koalicję, która pokazywała jedność narodów Rosji - realizując najwyraźniej bieżące cele polityczne władz ZSRR. „Kupiecko-rzemieślnicza ludność Niżnego Nowogrodu rzuciła hasło oswobodzenia ojczyzny. Na czele tego ruchu stanął starosta ziemski Kuźma Minin, naczelnikiem wojskowym został kniaź Pożarski. Do oddziałów Minina i Pożarskiego przybywały wciąż to nowe siły i to nie tylko rodowici Rosjanie, ale również Tatarzy, Mariowie, Czuwasze, Udmurtowie. [...] W październiku 1612 roku wojska polskie stacjonujące na Kremlu skapitulowały. Obca interwencja w Rosji została rozbita dzięki wytrwałości i męstwu narodów biorących udział w tej walce, a przede wszystkim narodu rosyjskiego" ${ }^{38}$.

${ }^{53}$ Siuchniński, Historia dla klasy VI, 142. Podobnie już wcześniej Moszczeńska, Mrozowska, Podręcznik historii część 1, 176: „Te wojny na wschodzie wyczerpywały siły naszego państwa i odwracały jego uwagę od ważnych spraw na zachodzie. [...] W owym czasie Polska mogła nie tylko odzyskać Śląsk, lecz także dopomóc narodowi czeskiemu, który podniósł wtedy bunt przeciw cesarzowi [...] Niestety, król i panowie polscy, obdarzali wielką przyjaźnią cesarza Niemiec, a o Śląsku nikt z nich nie myślał - woleli zdobywać ziemie na wschodzie. Czechy i Śląsk pozostały więc nadal pod panowaniem niemieckim”. Motyw powraca w podręczniku: Maria Dłuska, Janina Schoenbrenner, Historia. Dla klasy IV (Warszawa: PZWS, 1956) wyd. 4, 61-62 (ale tylko w tym jednym roku).

54 Moszczeńska, Mrozowska, Podręcznik historii część 1, 176.

55 Poza cytowanymi także np. Siuchniński, Historia dla klasy VI, 150; Chłapowski, Historia średniowieczna, 344; Kosman, Historia dla klasy VI, 93; Gierowski, Leszczyński, Historia dla klasy II liceum ogólnokształcacego, 216.

56 Kormanowa, Historia Polski, 85.

57 Arnold, Historia Polski do 1795 roku, 225; Chłapowski, Historia średniowieczna, 344; Hoszowska, Opowiadania z dziejów Polski. Część druga (1505-1648), 99.

58 Kosminski, Historia wieków średnich, 283 (wyd. z 1953); por. Moszczeńska, Mrozowska, Podręcznik historii część 1, 174-175. 
O ile wypędzenie Polaków bez wątpienia według autorów podręczników nastąpiło siłami narodu rosyjskiego, o tyle warto się przyjrzeć bliżej powodom, dla których Polacy opuszczali dwukrotnie mury Kremla. Do lat siedemdziesiątych w podręcznikach pojawiały się fragmenty o zuchwałym i grabieżczym charakterze polskiej okupacji, o panoszeniu się na Kremlu czy o niedbaniu o tradycje rosyjskie. W podręczniku rosyjskim czytamy: „Polacy i stronnicy rosyjscy, zuchwale rządzący się w Moskwie, zamierzali ogłosić króla Zygmunta carem Rosji i podporządkować państwo rosyjskie Polsce" 59 . Niewiele różniły się od niego książki polskiego autorstwa z końca lat czterdziestych i z pięćdziesiątych: „Zachowanie się polskiej szlachty otaczającej Dymitra, jej hulaszcze życie, lekceważenie okazywane tradycjom i obyczajom rosyjskim, zachowywanie się jak w kraju podbitym, trwonienie przez Dymitra pieniędzy ze skarbca carskiego wywołało powszechne oburzenie wszystkich warstw społeczeństwa rosyjskiego"60 albo: "gwałty, rabunki i bezprawia, jakich dopuszczały się wojska polskie na zajętych terenach, spowodowały wybuch wielkiego powstania przeciw obcej interwencji”' ${ }^{\prime 1}$. Praca Chłapowskiego wskazywała także na motyw polityczny: powstanie w Moskwie wybuchło, gdy okazało się, że Dymitr był narzędziem obcego państwa ${ }^{62}$.

W latach siedemdziesiątych i osiemdziesiątych ton ten nieco łagodnieje. Wprawdzie rządy Samozwańców wywołują ogólne niezadowolenie, ale ciężar przyczyn wybuchu powstania przesuwa się na próbę narzucenia katolicyzmu przez Zygmunta III Wazę i zagarnięcia przez niego carskiej korony. Jak uczył podręcznik dla szkoły podstawowej: „Jednak rządy Samozwańca wzbudziły ogólne niezadowolenie ludności. [...] Dążenie Zygmunta III do narzucenia Rosji katolicyzmu i jego zaborcza polityka wywołały oburzenie Rosjan. Wybuchło wielkie ogólnonarodowe powstanie przeciw wojskom polskim" ${ }^{63}$. Książka licealna nieco tylko rozwijała ten wywód: „Rządy Dymitra nie trwały długo. Niezadowolenie wzbudzały jego zatargi z kościołem prawosławnym oraz uleganie obcym, zwłaszcza polskim, doradcom. [...] Zażądał on [Zygmunt III Waza] tronu dla siebie, na co nie chcieli zgodzić się Rosjanie. Tymczasem Szwedzi zgłosili swego kandydata do tronu. Wszystko to zwiększyło ogólne zamieszanie, które powodowało narastanie oporu w Rosji przeciwko obcej interwencji ${ }^{64}$.

W ramach tego rozdziału warto także wspomnieć o odmiennym spojrzeniu na politykę państwa polskiego na początku XVI w. w podręcznikach dla szkoły podstawowej z końca lat czterdziestych. Dostrzegały one pozytywy strategii

59 Kosminski, Historia wieków średnich, 283 (wyd. z 1953).

60 Arnold, Historia Polski do 1795 roku, 225.

${ }_{61}$ Chłapowski, Historia średniowieczna, 344. Por. Hoszowska, Opowiadania z dziejów Polski. Część druga (1505-1648), 98; Moszczeńska, Mrozowska, Podręcznik historii część 1, 174-175.

62 Chłapowski, Historia średniowieczna, 342.

63 Szostakowski, Historia dla klasy VI, 98.

${ }^{64}$ Gierowski, Leszczyński, Historia dla klasy II liceum ogólnokształcacego, 216. 
politycznej Stefana Żółkiewskiego stworzenia unii z Rosją. Nie chodziło tam o grabież Moskwy czy krótkotrwałe zdobycze terytorialne, lecz o dalekosiężny program działań, przedstawiany zresztą z dużą dozą empatii dla hetmana: „Natomiast hetman Żółkiewski był przeciwny wojnie. Marzył on o unii Polski z Moskwą, o wspólnej wyprawie na najpotężniejszego w owych czasach wroga - Turków. Nie mógł przeszkodzić wojnie, ale gdy jako zwycięzca stanął pod Moskwą, rozpoczął układy o trwały pokój i zgodę"65; „Zamyślony na wschód jechał Stanisław Żółkiewski. Dalej on patrzył, niż wielu innych. [...] [M]yślał o rzeczy najważniejszej. Oto należałoby usunąć i załagodzić spory, jakie panowały od wielu lat pomiędzy Litwinami i Polakami a Księstwem Moskiewskim. [...] Wszystko to zostałoby załagodzone, gdyby jeden władca zaczął rządzić w obu państwach. [...] Ku podziwowi wszystkich [Żółkiewski] pokonał pod Kłuszynem wielokroć liczniejszego nieprzyjaciela. Droga do Moskwy stała otworem. Ruszył tam i wkrótce stanął pod stolicą carów. Ale nie myślał zdobywać jej siłą. Żółkiewski rozpoczął narady z przedstawicielami narodu rosyjskiego. [...] Radował się Żółkiewski, że dojdzie do skutku myśl połączenia Polski i Rusi w jedno wielkie państwo. [...] Niestety plany Żółkiewskiego nie ziściły się. Stanął im na przeszkodzie król Polski Zygmunt"66.

Wydaje się, że program Żółkiewskiego można byłoby wykorzystać propagandowo, ukazać jako próbę budowy wielonarodowego państwa opartego na Słowianach, którzy pokojowo współegzystują z innymi narodami, tak jak według oficjalnej wykładni postępował Związek Radziecki. Tak się jednak nie stało, być może dlatego, że unia ta miała być tworzona pod przewodnictwem Polski, a nie Rosji. Pozytywna ocena hetmana była widoczna natomiast także w podręcznikach autorstwa Hoszowskiej wydawanych na przełomie lat pięćdziesiątych i sześćdziesiątych, gdzie przedstawiano go jako tego, który był „stanowczym przeciwnikiem tych awanturniczych planów [dymitriad]"67.

Przez cały czas Polski Ludowej dymitriady były prezentowane bardziej z rosyjskiego niż z polskiego punktu widzenia. Czyniono wiele, by pokazać, że nie było to działanie polskiego państwa, lecz raczej grup awanturników ze strony polskiej lub zepsutych bojarów - z rosyjskiej, a najgorszą rolę w tych przedsięwzięciach odegrał król. Takie ujęcie wymagało swego rodzaju ekwilibrystyki - wydaje się, że wejście wojsk polskich na Kreml mogło budzić naturalną dumę u odbiorców, a podręcznikowa interpretacja była tu zgoła odmienna. Widać również klasowe podejście do opisu wydarzeń historycznych.

65 Moszczeńska, Mrozowska, Podręcznik historii. Część 1, 153 (wyd. 1947); Moszczeńska, Mrozowska, Podręcznik historii. Część 1, 175 (wyd. 1948).

${ }_{66}$ Hoszowska, Szczechura, Tropaczyńska-Ogarkowa, Było to dawno - opowiadania z dziejów ojczystych dla IV klasy szkoły podstawowej, 178-179.

${ }_{67}$ Hoszowska, Opowiadania z dziejów Polski. Część druga (1505-1648), 98. 


\section{Podsumowanie}

Analiza narracji podręcznikowej ukazuje, że największa ideologizacja treści nauczania występowała w pierwszej połowie lat pięćdziesiątych, a więc w czasach stalinowskich. Zostało to także dostrzeżone przez innych badaczy ${ }^{68}$. Wtedy też szeroko rozumianej Rosji programy nauczania i książki szkolne poświęcały najwięcej miejsca, zaś zatwierdzone do użytku szkolnego w Polsce tłumaczenia radzieckich podręczników do dziejów powszechnych prezentowały radziecki (a często po prostu rosyjski) punkt widzenia na przeszłość. Charakterystyczny dla lat pięćdziesiątych był bardzo emocjonalny język narracji. Z kolejnymi dekadami nasycenie ideologiczne podręczników maleje, choć dalekie od prawdy byłoby stwierdzenie, że znika ono zupełnie.

Rzuca się także w oczy marksistowski czy marksizujący język narracji - odwołujący się do teorii walki klas, widoczny zwłaszcza w latach pięćdziesiątych. Książki pierwszej dekady PRL są nim bardzo mocno naznaczone, a odniesienia do teorii marksizmu-leninizmu silnie widoczne w narracji. To wówczas także próbowano - podobnie jak w akademickiej historiografii ${ }^{69}$ - wprowadzać nową periodyzację dziejów, opartą na formacjach ustrojowych. Jak wiadomo, w historiografii z doktrynalnego marksizmu zrezygnowano po 1956 r. Podobnie w podręcznikach można zaobserwować, że języka marksistowskiego jest coraz mniej, a walka klas nie jest jedynym przedmiotem zainteresowania autorów. I znowu, tak jak w świecie akademickim, żaden $\mathrm{z}$ tych elementów nie znika jednak zupełnie. Wypadałoby się zatem, przynajmniej częściowo, zgodzić z Józefem Brynkusem, który w swojej pracy podkreśla, że szkolna historia przez cały okres PRL miała służyć komunizacji dzieci i młodzieży; nawet jeśli zmieniały się formy, to istota pozostawała bez zmian ${ }^{70}$.

Nie można natomiast zgodzić się z jego tezą, że edukację w PRL należy traktować jako całość, a zmiany były tylko kosmetyczne. W przeciwieństwie do czasów stalinowskich, w późniejszych dekadach (im bliżej schyłku PRL, tym bardziej ten trend jest widoczny) uczeń mógł odpocząć czasami od ideologicznych dywagacji i marksistowskiego języka. Zmianę tę widać szczególnie, jeśli porównamy lata pięćdziesiąte z osiemdziesiątymi.

W podręcznikach stale widoczna jest dość silna propaganda polityczna rozumiana jako wykorzystanie narracji historycznej do bieżących kampanii politycznych i propagandowych. Interesującym motywem jest próba pokazania jedności

68 Brynkus, Komunistyczna ideologizacja a szkolna edukacja historyczna w Polsce (1944-1989); Osiński, Nauczanie historii w szkołach podstawowych w Polsce w latach 1944-1989; Wojdon, Propaganda polityczna w podręcznikach dla szkół podstawowych Polski Ludowej (1944-1989).

${ }_{69}$ Rafał Stobiecki, Historiografia PRL. Ani dobra, ani mądra, ani piękna... ale skomplikowana (Warszawa: TRIO, 2007); Marek Górny, Przede wszystkim ma być naród. Marksistowskie historiografie w Europie Środkowo-Wschodniej (Warszawa: TRIO, 2007).

70 Brynkus, Komunistyczna ideologizacja a szkolna edukacja historyczna w Polsce 1944-1989). 
Słowian czy stawianie jako głównego wroga Niemców, ale również sprawa polskiej granicy wschodniej i zachodniej. Polska prowadziła zatem walki na zachodzie z zamiarem „odzyskania prastarych ziem piastowskich”. Walki na wschodzie natomiast były najczęściej określane jako zaborcze i niesprawiedliwe, służące tylko wąskiej grupie (czy raczej klasie) obszarników, ewentualnie katolickiego duchowieństwa.

Marcin Dyś

Changes in narration describing Polish-Russian relations in history teaching course books in Polish People's Republic from 1944 to 1989

(based on selected historical events)

\section{Summary}

The article shows how certain historical events were described in history teaching course books in Polish People's Republic from 1944 to 1989. The author chose two important events from the Polish history - the battle of Grunwald and Polish interventions in Russia at the beginning of the 17th century.

The first event was chosen because the Polish army during the battle was supported among others by Russian and Lithuanian forces and that fact could be easily used by communist propaganda to underline Slavic unity, brotherhood and to show who the real enemy is/was (in simplification Germany).

The second event was chosen because the course books authors had to be very creative to conciliate two contradict interests and points of views (Polish and Russian) on that interventions.

Propaganda, very emotional language and ideologisation of the course books is easily visible especially in the late ' 40 s and early ' 50 s. History is combined with Marx's theory of the class struggle. Later those factors are also present but not as much as at the beginning of the communist period in Poland. However they never disappear completely. 